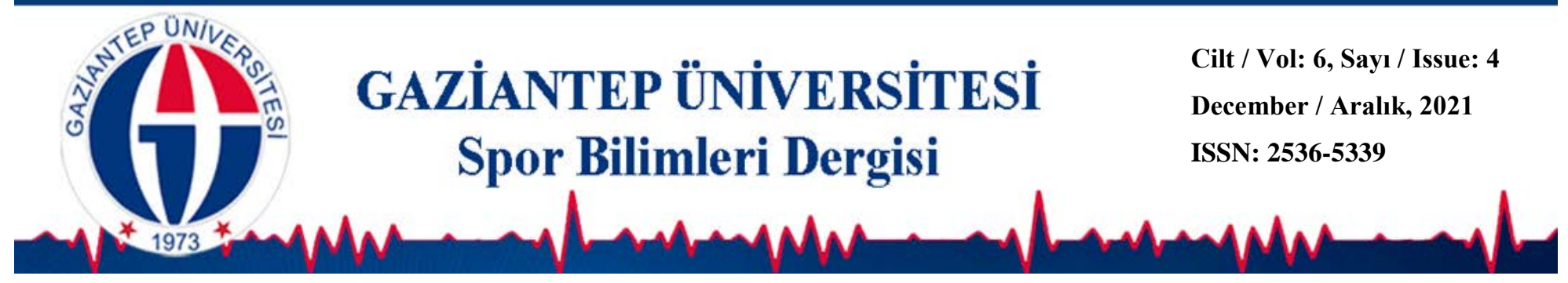

\title{
Türkiye ve İtalya Spor Kulüplerinin Örgütsel Yapılarının Kıyaslamalı Analizi
}

\author{
İlker DiLEK ${ }^{1 *}$ (D) \\ Lütfi ARSLAN²i \\ ${ }^{1}$ Türkiye Büyük Millet Meclisi, ANKARA \\ ${ }^{2}$ Milli Eğitim Müdürlüğü, YOZGAT
}

d. DOI: $10.31680 /$ gaunjss.987258

Orijinal Makale / Original Article

Geliş Tarihi / Received: 26.08.2021 Kabul Tarihi / Accepted: 11.03.2021

Yayın Tarihi / Published: 24.12.2021

\section{Öz}

Spor yönetiminin temel birimi olarak tanımlanan spor kulüpleri, insanların spor yapmak amacıyla bir araya gelerek örgütlendikleri toplumsal olgulardan biridir. Dünyada yaşanan küreselleşmeyle birlikte spor yönetiminde yaşanan gelişmeler, spor kulüplerinin yönetsel yapısına da yansımaktadır. Türkiye ve İtalya'daki spor kulüpleri örgütlenmeleri, bağlı oldukları hukuki yapı, denetlenmeleri, federasyonların başkanlık seçimindeki oy kullanma şekilleri konularında benzerlikleri bulunmaktadır. Ancak uygulama aşamasında farklılıklar görülmektedir. Dikkate değer farklılıklardan en önemlisi İtalya'da spor kulüplerinin örgütsel yapılarının daha çok amatör ve profesyonel spor kulüpleri olarak mevzuatta tanımlanmalarıdır. Türkiye'de ise kulüplerin branş olarak incelenip profesyonel faaliyetleri için şirketleşmelerine izin verilmektedir. İtalya'da spor kulüpleri, ilgili spor federasyonları tarafından denetlenmektedir. Türkiye'de ise sportif faaliyet gösteren kulüpler lüzumlu hallerde Gençlik ve Spor Bakanlığı'nın ilgili birimleri ve Gençlik Hizmetleri ve Spor İI Müdürlüklerince denetlenmektedir. Türkiye ve İtalya'da spor kulüpleri kuruluş, tüzük ve asgari gereklilikler bakımından benzerlik göstermektedir.

Anahtar Kelimeler: Amatör, Dernek, Kulüp, Örgüt, Tüzük, Denetim

\section{Comparative Analysis of Organizational Structures of Turkish and Italian Sports Clubs}

\begin{abstract}
Sports clubs, which are defined as the basic unit of sports management, are one of the social phenomena in which people come together to do sports. With the globalization in the world, the developments in sports management are also reflected in the managerial structure of sports clubs. There are similarities in the organization of sports clubs in Turkey and Italy, the legal structure they are affiliated with, their supervision, and the way the federations vote in the presidential election. However, there are differences in the implementation phase. The most important difference is that the organizational structures of sports clubs in Italy are defined in the legislation as amateur and professional sports clubs. In Turkey, clubs are allowed to be examined as branches and incorporated for their professional activities. Sports clubs in Italy are supervised by the relevant sports federations. In Turkey, sports clubs are inspected by the relevant units of the Ministry of Youth and Sports and Provincial Directorates of Youth Services and Sports, when necessary. Sports clubs in Turkey and Italy are similar in terms of establishment, statute and minimum requirements.
\end{abstract}

Keywords: Amateur, Association, Club, Organization, Bylaw, Audit

\footnotetext{
*Sorumlu Yazar: İlker DİLEK

e-mail: ilkerrdilek@gmail.com *Bu çalışma, Spor Yönetimi Anabilim Dalında, İlker Dilek Tarafindan hazırlanan Yüksek Lisans Tezinden üretilmiştir.
} 


\section{Giriş}

Sportif faaliyetlerin bir ülkede geniş kitlelere yayılabilmesi şüphesiz örgütsel olarak yapılanmasından geçmektedir. Her ne kadar kimi ülkelerde resmi olmayan prosedürle çeşitli örgütsel yöntemler oluşturulsa da kulüplerin devletin denetimi ve korumasında varlıklarını sürdürmesi vazgeçilmez bir durum arz etmektedir. Toplumsal farkındalıkların oluşmasıyla spora karşı oluşan yoğun talep sporun endüstrileşmesine ve kâr amacı güdülerek yapılan bir aktivite olmasına yol açmıştır. Böylece kulüpleşmelerde pazar, idare veya organize etme gibi roller ortaya çıkmıştır (Süreç ve Aktifler, 2009). Nihayet sporun ana aktif unsuru durumunda olan spor kulüpleri, uluslararası sportif faaliyetlerden başka ekonomide de yarış halinde olan kuruluşlar olarak yerini almıştır. Böylece spor "beden hareketleri” noktasından çıkıp, ekonomiyle iç içe girmiş bir durum göstermektedir (Ekenci, 1997). Ekonomiden spora birçok alanda insan hayatının vazgeçilmez unsurlarından birinin yarış ve yarışmak olduğu dikkate alındığında birbirinden farklı sosyokültürel toplumları ve o toplumların kurum ve kuruluşlarını karşılaştırmak doğal bir sonuçtur. Bu çalışma bu gereklerden yola çıkılarak hazırlanmıştır. Spor alanında daha iyi stratejik planlama ve politikanın oluşması için de istatistiki verilerin karşılaştırma yapılarak ele alınması oldukça önem taşımaktadır (Ecer 2009).

Sosyal bilimlerin tüm bölümlerinde olduğu gibi sporda da kıyaslama, dünyadaki spor sistemlerinin yapısal durumları, özellikleri, devlet ile olan bağları, yönetim erklerinin kimlerden müteşekkil olduğu, seçim şekilleri, bağlı oldukları hukuki alt yapı, izledikleri yöntemleri tespit etmemize fayda sağlamaktadır. Bu araştırmada sportif faaliyet gösteren kuruluşların Türkiye ve İtalya'daki güncel durumları, örgütsel yapılanmaları, fonksiyonları, devlet ile olan ilişkileri ve denetlenmeleri üzerinden benzerlik ve farklılıkları ortaya konulmaya çalışılmıştır.

\section{Yöntem}

Bu araştırma, Türkiye ve İtalya'daki spor kulüplerinin farklı ve benzer yönlerden nitel olarak karşılaştırılmasına yönelik bir çalışmadır. Araştırmada iki farklı yöntem kullanılmıştır. Birinci yöntem tarama modelindedir. İkinci yöntem karşılaştırmalı yöntemdir. 
Dilek İ, Arslan L. (2021). Türkiye ve İtalya Spor Kulüplerinin Örgütsel Yapılarının Kıyaslamalı Analizi. Gaziantep Üniversitesi Spor Bilimleri Dergisi, 6(4), 311-328.

\section{Araştırmanın Modeli}

Araştırmada tarama ve karşılaştırma modelleri kullanılmıştır. Birinci yöntem tarama modelindedir. Tarama modeli, var olan bir durumu var olduğu şekliyle açıklamayı amaç edinen araştırma yaklaşımlarından biridir. Araştırmaya konu olan olay, birey ya da nesne, kendi koşulları içinde ve olduğu gibi tanımlanmaya çalışılır (Karasar, 2007). İkinci yöntem karşılaştırmalı yöntemdir. Karşılaştırma, benzer ya da farklılıkların ortaya çıkarılmasıdır. Karşılaştırmalı yöntem, geliştirilmiş ve açık bir biçimde tanımlanmış varsayımları deneme yöntemidir. Pozitif bilimlerdeki gibi deney yapmak çok güç ve sınırlı olduğundan, bu eksikliği gidermek için sosyal bilimlerde bu yönteme başvurulmaktadır. (Arslanoğlu, 2012; Kırcaali, 1999) Bu araştırma, gözlem, doküman analizi gibi niteliksel veri toplama yöntemleri kullanılmıştır.

\section{Evren ve Örneklem}

Araştırma için oluşturulan araştırmanın evreni, araştırma bulgularının genellendiği Türkiye ve İtalya'daki spor kulüplerinin bütününü oluşturmaktadır. Araştırmanın örneklemi, evrene genelleme yapmaya fırsat verecek şekilde araştırma öncesinde belirlenen olgulardan meydana gelmektedir. Örneklemden elde edilen araştırma sonuçları ise tüm evreni temsil edecek şekildedir.

\section{Verilerin Toplanması}

Bu araştırmada gözlem ve doküman analizi gibi nitel veri toplama yöntemleri kullanılarak, algı ve olaylar bütüncül bir biçimde ortaya konulmuştur.

\section{Verilerin analizi}

Gözlem ve dokümanlar yoluyla elde edilen nitel araştırma verilerinin analiz sürecinde verilerin kodlanması, temaların bulunması, kodların ve temaların düzenlenmesi ve bulguların tanımlanması ve yorumlanması yapılmıştır.

\section{KARŞILAŞTIRMALI SPOR YÖNETIMI}

\section{Karşılaştırmalı Spor Yönetimi ve Bazı Temel Kavramlar}

Sporda karşılaştırma, bir spor örgütünün güçlü ve zayıf yönleri ile sahip olduğu fırsatların neler olduğunun görülebilmesi hakkında fonksiyonel bir yol takip edilmesini sağlamaktadır. Karşılaştırma tekniğinin ana amacı sportif yapılanmaların performans ve yönetim kalitelerini yükseltmektir. Bu hedef yönünde sportif örgütlenmelerin başarılarını etkileyen faktörler ile eksikliklerinin tespit edilerek giderilmesini sağlamaktadır. Karşılaştırma yönteminin temel kavramları olarak ölçüm, benzerlik, 
Dilek İ, Arslan L. (2021). Türkiye ve İtalya Spor Kulüplerinin Örgütsel Yapılarının Kıyaslamalı Analizi. Gaziantep Üniversitesi Spor Bilimleri Dergisi, 6(4), 311-328.

karşılıklılık, doğruluk, rekabet, müşteri memnuniyeti ve devamlı gelişim durumları sayılabilir (Sunay 2009).

\section{Dünyada Uygulanan Karşılaştırma Yöntemleri}

Sportif faaliyet gösteren kuruluşlarda kıyaslama veya karşılaştırma yöntemleri, devletlerin üst spor yönetim organlarında, federasyonlar, kulüpler, ulusal ve uluslararası spor aktivitelerinde uygulanmaktadır. Kıyaslanan kuruluşların aynı zamanda içerik olarak da değerlendirmeye tabi tutulması gerekir (Genç, 1998). Böylece karşılaştırılan veya kıyaslanan şeylerin kendi içerisinde ve ayrıca ait oldukları bütüne göre durumları bakımından ayrıntılı olarak incelenmeleri gerektirmektedir. Karşılaştırmalı yönetim metodu dünyada ilk kez XIX. Yüzyılda İngiliz filozof ve ekonomist John Stuart Mill tarafından yapılmıştır. Mill, kıyaslanan şeylerin fonksiyonel bağlılıklarını çözümleyebilmek için gözlem, çözümleme ve yorumlama aracı olarak değişik yöntem ve teknikleri kullanmıştır. Uygunluk yöntemi, farklılık yöntemi, karma yöntem, birlikte değişim ve kalıntılar yöntemleri bunlardan bazılarıdır. Mill'in kullandığı yöntemler haricinde dünyada kullanılan diğer yöntemler ise niteliksel ve niceliksel araştırma yöntemi, bulanık küme yöntemi vb. dir (Sunay 2009).

\section{TÜRKIYE SPOR KULÜPLERININ ÖRGÜTSEL GELIŞIMI}

\section{Spor Kulüplerinin Örgütsel Yapısı}

Türkiye'de spor kulüpleri yapısal ve örgütsel olarak gerçek kimliğine ancak Cumhuriyet Dönemi'nde ulaşmıştır. Cumhuriyet Döneminin ilk senelerinde spor kulüplerine tam olarak bir amatörlük hâkim durumdayken, 1947-1949 yıllarında kulüplere 'gizli profesyonellik' olgusu tesir etmiştir. 1952 tarihinde Türkiye'de futbol alanında beş takımın profesyonel olarak resmen kabulü gerçekleşmiş olup, mevzuatta belirtilen kurallara uygun oldukları belirlenen birçok amatör spor kulübüne profesyonel takım kurabilme hakkı tanınmıştır. Türkiye'de sportif faaliyetlerde ciddi bir yeri bulunan spor kulüpleri, derneklerin özel bir türü olarak vasıflandırılmıştır. Özel hukuk tüzel kişiliğe sahip olan tüm sportif kulüpler, 5253 Sayılı Dernekler Kanunu'na göre şekillenmiş olup, kayıtları resmi olarak başladıktan sonra Spor Genel Müdürlüğü'ne tabi hale gelmektedir. Spor kulüpleri 5253 Sayılı Dernekler Kanunu'nun "Gençlik ve Spor Kulüpleri” başlıklı 14 maddesinde tanımlanmıştır. Buna göre, kulüpler gençlik kulübü, spor ve gençlik kulübü ile spor kulüpleri olarak sınıflandırılmaktadır. Spor kulüpleri, Gençlik ve Spor Bakanlığı Spor Genel Müdürlüğü tarafından kayıtları alınan 
Dilek İ, Arslan L. (2021). Türkiye ve İtalya Spor Kulüplerinin Örgütsel Yapılarının Kıyaslamalı Analizi. Gaziantep Üniversitesi Spor Bilimleri Dergisi, 6(4), 311-328.

bir kütüğe tescil edilmektedir. Sportif faaliyetlere katılmak için kurulan derneklerin, kayıt ve tescillerinin yapılabilmesi için Spor Kulüpleri Tescil Yönetmeliği hazırlanmıştır. Kayıt ve tescilleri gerçekleştirilmiş olan spor kulüplerinin yetkileri ve görevleri, denetimleri Gençlik ve Spor Kulüpleri Yönetmeliği ile yapılmaktadır. Yalnızca futbol türünde faaliyet gösteren ve hukuki şartları taşıyan spor kulüpleri Türkiye Futbol Federasyonu "Futbol Kulüplerinin Tescil Yönetmeliği” ile tescil edilirler. Türkiye'de derneklerin sportif faaliyetlere yönelik olanları spor kulübü, boş vakitleri değerlendirme faaliyetine yönelik olanları gençlik kulübü ve her iki faaliyeti birlikte gerçekleştirenlere de gençlik ve spor kulübü adı verilmiştir (Ertaş ve Petek, 2005). Kulüpler ve bağlı unsurları görev ve yetkileri, tabi oldukları "Gençlik ve Spor Kulüpleri Yönetmeliği" ne göre örgütlenmektedir. Spor kulüplerinin kendilerine ait bir tüzükleri de vardır. Sportif faaliyetlerde bulunan bazı dernekler, en az 7 kişi tarafından, kamu kurum ve kuruluşlarda, yükseköğrenim kurumlarında, özel kuruluşlarda mensuplarınca kurulabileceği gibi kişilerin müracaatları ile de kurulabilmektedir. Türkiye'de spor kulüplerinin halka arzı ile diğer halka arzı olan şirketlerde olduğu gibi, anonim şirket şeklinde örgütlenmeleri de mümkündür (Aydın, 2005). Türkiye'de spor kulüpleri yürürlükteki şartlara göre iki yolla yapılandırımıştır. Bunlardan biri Dernekler Kanunu'na göre yapılanan kulüpler, diğeri ise Türk Ticaret Kanunu'na göre kurulan spor kulüpleridir. Dernekler Kanunu'na göre kurulan spor kulüpleri, şubelerini kuracakları veya kurulmuş olan bir şirkete devredebilmektedir (Yıldız, 2009).

Dernekler Kanunu'nun konuyla ilgili hükümlerine göre, derneklerin tüzüğünde genel kurulun toplanma şekil zamanı, oy kullanma ve karar alma yöntem ve teknikleri de belirtilmek zorundadır. 22 Kasım 2001 'de kabul edilen ve 1 Ocak 2002'de yürürlüğe giren 4721 Sayılı Medeni Kanun'a göre, olağan genel kurul toplantıları üç senede bir gerçekleştirilir. Spor kulüplerinde, olağan ve olağanüstü olarak iki çeşit genel kurul toplantısı yapılmaktadır (Ertaş ve Petek 2005). Yönetim kurulunun lüzumu halinde veya dernek üyelerinden beşte birinin yazılı talebiyle genel kurul olağanüstü toplanmaktadır. Hukuki olarak genel kurul, kulübün en yetkili karar organıdır. Genel kurulun kaç üyeden oluşacağı ve üyelerin belirlenme yöntemleri tüzüklerinde yer almaktadır. Kulübe kayıtlı üyeler haricinde genel kurula üye alınamaz (Üçışık, 2011).

Gençlik ve Spor Kulüpleri Yönetmeliği'nin 15 maddesine göre kurulun görev ve yetkileri şu şekilde düzenlenmiştir; a. Kulüp organları seçimi, b. Kulüp tüzüğünün değiştirilmesi, c. Yönetim ve denetleme kurulu raporlarının görüşülmesi, yönetim 
Dilek İ, Arslan L. (2021). Türkiye ve İtalya Spor Kulüplerinin Örgütsel Yapılarının Kıyaslamalı Analizi. Gaziantep Üniversitesi Spor Bilimleri Dergisi, 6(4), 311-328.

kurulunun ibra edilmesi, d. Yönetim kurulunca hazırlanan bütçenin görüşülüp aynen veya değiştirilerek kabul edilmesi, e. Kulüp için gerekli taşınmaz malların satın alınması veya mevcut taşınmaz satılması hususunda yönetim kuruluna yetki verilmesi, $\mathrm{f}$. Kulüplerin federasyona katılması veya ayrılması, g. Kulüplerin milletlerarası faaliyette bulunması, yurtdışındaki kulüp veya kuruluşlara üye olarak katılması ve ayrılması, h. Kulübün feshedilmesi, i. Mevzuatta ve kulüp tüzüğünde genel kurulca yapılması belirtilen diğer görevlerin yerine getirilmesi (Gençlik ve Spor Kulüpleri Yönetmeliği, 2005).

Yönetim kurulunun kulübü içerden idare edip, dışarıya karşı da onu temsil eden bir yapısı vardır. Yönetim kurulunun sorumluluk ile yetkileri, Gençlik ve Spor Kulüpleri Yönetmeliği'nin 16. maddesinin ikinci fıkrasında açıkça belirtilmiştir (Gençlik ve Spor Kulüpleri Yönetmeliği, 2005). Spor kulüplerinde, denetim kurulu mecburi olan bir kuruldur. Kulüp tüzüğünde belirtilen usullere göre denetim yapmaktadır. Denetim Kurulu üç asil ve üç yedek üyeden oluşur. Denetim Kurulu, kulüp tüzüğünde belirlenen usullere göre denetimini gerçekleştirerek, raporunu yönetim kuruluna ve genel kurula sunar (Üçısık, 2011) Spor kulüplerinde, yürütme birimi, genel sekreter ve ona bağlı çalışan maaşlı ve gönüllü kişilerden oluşmaktadır. Yürütme biriminin sorumlusu genel sekreterdir. Genel sekreter; gençlik ve spor mevzuatına ve yönetim kurulu kararlarına göre kulübün amaçladığı faaliyetlerle idari, mali ve teknik olarak tüm işlerin yapılmasını sağlar. (Üçışık, 2011).

\section{Türkiye'de Spor Kulüplerinin Yapılanma Şekilleri}

Türkiye'de sportif faaliyette bulunan kulüplerinin örgütsel yapıları 5253 Sayılı Dernekler Kanunu'na göre belirlenmiştir. Türkiye'de Dernekler Kanunu ile teşkilatlanış olan ve Spor Genel Müdürlüğü'ne bağlı kulüpler, sadece Dernekler Kanunu'na göre kâr amacı taşımayan özel hukuk tüzel kişiliğine sahip dernekler olarak örgütlenebilmiştir. Türkiye'deki spor kulüplerinin Türk vergi mevzuatına göre dernekler statüsünde sayılmaları nedeniyle vergi mükellefi değildirler. Ancak, kulüplerin ticari işletmeleri bulunuyorsa bunlar kurumlar vergisine tabidir (Erturan, 2010).

Endüstrileşme yolunda Türkiye'deki spor kulüpleri, kendilerine ekonomik destek sağlayabilmek için şirketleşmek zorunda kalmışlardır. Spor kulüplerinin bu durumu onlara aslında kurumsallaşma ve profesyonelleşmeyi de beraberinde getiren fırsatlar sunmuştur (Akşar, 2005). Şirketleşmiş kulüpler, şirket statüsüyle örgütlenmiş, 
Dilek İ, Arslan L. (2021). Türkiye ve İtalya Spor Kulüplerinin Örgütsel Yapılarının Kıyaslamalı Analizi. Gaziantep Üniversitesi Spor Bilimleri Dergisi, 6(4), 311-328.

sporcularıyla ilişkilerini işçi-işveren şeklinde düzenleyen ve adına "Lig" adı verilen konfedere yönetsel bir yapıya sahip olmuşlardır (Fişek 2003). Türkiye'de futbol takımlarının anonim şirket olmaya başlamasıyla birlikte kulüpler spor ekonomisinin ciddi aktörlerinden biri haline gelmiştir.

5253 Sayılı Dernekler Kanunu'na göre kurulmuş ve Spor Genel Müdürlüğü'ne kayıtları gerçekleştirildikten sonra kulüp maiyeti kazanan kulüpler futbol branşında ve Türkiye Futbol Federasyonu Mevzuatı içerisinde faaliyet gösteren, Türkiye Futbol Federasyonu'na kayıtlı ve Türk Ticaret Kanunu hükümleri uyarınca kurulmuş "Profesyonel Futbol Hizmetleri Anonim Şirketi” statüsü almışlardır. (Dernekler Kanunu, 2004). Ayrıca 3289 Sayılı Spor Genel Müdürlüğü Kuruluş ve Görevleri Hakkında Kanun'un 24 maddesi ve 5894 Sayılı Türkiye Futbol Federasyonu Kuruluş ve Görevleri Hakkında Kanun'un 27 maddesince kulüplere profesyonel şubelerini anonim şirketlere devir veya spor faaliyetleri ile ilgili anonim şirket kurabilme hakkı da verilmiştir (Devecioğlu, Çoban ark. 2011).

Gençlik ve Spor Bakanlığı Spor Genel Müdürlüğü yardımından spor kulüplerine yapılacak olan ayni ve nakdi destek şartları yönetmelikle belirlenmiştir. Yardım ödeneğinden spor kulüplerine; malzeme, araç-gereç, tesis yapımı, bakım-onarım, eğitim, bilim, kültür ve sanat faaliyetleri, sağlık hizmetleri, sigortalama ve sosyal güvenlik hizmetleri, kira vb. zorunlu harcamalar için kullanılmak üzere il müdürlükleri vasıtasıyla yardım yapılmaktadır (Üçışık, 2011). Spor kulüpleri, 5253 Sayılı Dernekler Kanunu'nun "Gençlik ve Spor Kulüpleri” isimli kısmında 14 madde ile düzenlenmiştir. Buna göre; derneklerden başvuruları durumunda, sportif çalışmalara yönelik olanlar spor kulübü, boş zamanları değerlendirmeye yönelik olanlar gençlik kulübü ve her iki çalışmaları birlikte gerçekleştirenler gençlik ve spor kulübü adını almaktadır. Bu kulüpler, Gençlik ve Spor Bakanlığı Spor Genel Müdürlüğü' ne bağlı Gençlik Hizmetleri ve Spor İI Müdürlükleri tarafından tutulan bir kütüğe kayıt ve tescil edilirler. Spor kulüplerinin, Gençlik ve Spor Bakanlığı Spor Genel Müdürlüğü tarafından kayıt ve tescil olunmaları için 2908 Sayılı Dernekler Kanunu'na uygun "Spor Kulüpleri Tescil Yönetmeliği” düzenlenmiştir (Spor Kulüpleri Tescil Yönetmeliği, 1983).

Spor kulüpleri, 5253 Sayılı Dernekler Kanunu'na tabii olarak Gençlik ve Spor Bakanlığı Spor Genel Müdürlüğünce kayıt ve tescilleri yapılmaktadır. Ancak böylece tüzel kişilik vasfını kazanmış olurlar. Spor kulüpleri, sivil toplum kuruluşları gibi denetlenmektedirler. Spor kulüplerinde, mecburi bir kurul olan denetim kurulu, kulüp 
Dilek İ, Arslan L. (2021). Türkiye ve İtalya Spor Kulüplerinin Örgütsel Yapılarının Kıyaslamalı Analizi. Gaziantep Üniversitesi Spor Bilimleri Dergisi, 6(4), 311-328.

tüzüğünde belirtilen usullere göre denetleme görevini yapmaktadır (Resmî Gazete, 2004). 3289 Sayılı Spor Genel Müdürlüğü Teşkilat ve Görevleri Hakkında Kanun'un 21 maddesine göre Gençlik ve Spor Bakanlığına bağlı Spor Genel Müdürlüğü kulüpleri her açıdan denetler (Spor Genel Müdürlüğü Teşkilat ve Görevleri Hakkında Kanun, 1986). Lüzumu halinde hesap, defterlerine el koyabilir.

\section{ITALYA'DA SPOR KULÜPLERININ ÖRGÜTSEL GELIŞIMI}

\section{Spor Kulüplerinin Örgütsel Yapısı}

İtalya'da spor faaliyetleri, Spor Kanunu ve Profesyonel Spor Kanunu ile yapılmaktadır. İtalya Milli Olimpiyat Komitesi (CONI) ile düzenlenen yönergelere göre, İtalyan Spor federasyonu sporcuların profesyonel olarak sportif çalışmalara katılmasına izin vermektedir. İtalya'da profesyonel sporun örgütlenmesi merkezi kurallara göre düzenlenmiştir. Profesyonel spor faaliyetleri 1980 tarih ve 91 Sayılı Kanun, hizmet sözleşmeleri ve bu Kanun ve IOC, CONI tarafından verilen yönergelere uygun olarak hazırlanan Ulusal Spor Federasyonları tarafından düzenlenen yönetmeliklerle gerçekleştirilmektedir. İtalya Spor Federasyonları özerk olarak üyesi ve bağlı oldukları Avrupa Uluslararası Spor Federasyonları tarafından konulan 14 uluslararası spor kuralına tabidirler. İtalya Ulusal Spor Federasyonları CONI tarafından da denetlenmektedirler. CONI bağımız tüzel kişiliğe sahip bir kamu kuruluşu olup, Kültürel Miras ve Aktiviteler Bakanlığı gözetiminde bulunmaktadır. İtalyan Spor Federasyonları İtalya Medeni Hukuku ile düzenlenen tüzel kişiliğe sahip özel birliklerdir. Ulusal Spor Federasyonları, ulusal ve uluslararası spor kurallarına uygun, eşit şartlarda herkesin spor çalışmalarına katılmalarında demokratik ilkelere dayalı şart ve yönetmeliklerle idare edilmektedir (CONI, 2012). Devlet, CONI'ye spor sektöründe her türlü düzenleme izni vermiştir. CONI'nin Ulusal Konseyi, uluslararası spor kurallarına uyarak, her Ulusal Spor Federasyon kapsamında, profesyonel ve profesyonel olmayan şeklinde takip edilecek spor çalışmalarını birbirinden ayırt etmek için bir kriter oluşturmuştur. Devlet doğrudan Hesap Denetçileri Yüksekokulu'na bağlı 5 üye dışında iki kişiyi daha görevlendirmiştir. Bunlardan biri Kültürel Miras ve Faaliyetleri Bakanı tarafından ve diğerleri Ekonomi Bakanı tarafından atanmaktadır. Diğeri ise CONI tarafından seçilmektedir. CONI tüm görev ve çalışmalarını, "Coni Servizi Spa" adlı limited şirket vasıtasıyla yerine getirmektedir (European Sports Commission, 2011). 
Dilek İ, Arslan L. (2021). Türkiye ve İtalya Spor Kulüplerinin Örgütsel Yapılarının Kıyaslamalı Analizi. Gaziantep Üniversitesi Spor Bilimleri Dergisi, 6(4), 311-328.

İtalya'da spor kulüpleri 1991 tarih ve 81 Sayılı Kanun'un “kulüpler ve profesyonel sporcular arasındaki ilişkilere yönelik kurallar" kısmı ile 2002 tarih ve 289 Sayılı Kanun'un 90 maddesinde belirtilen "Amatör Sportif Faaliyetleri için Düzenlemeler" isimli kısmına göre yapılanmıştır. 2003 tarih ve 220 Sayılı Kanun Hükmünde Kararname, 280/2003 tarih ve sayı ile değişen "Spor Hukukuna Ilişsin Acil Kararname" ile yeniden düzenlenmektir. Ayrıca 1999 tarih ve 242 Sayılı Kanun Hükmünde Kararname ile Italya'da spor otoritesi olarak tanımlanan İtalya Ulusal Olimpiyat Komitesi (CONi) tüzüğü sportif faaliyetlerin yasal düzenleyicisi durumundadır (Turismo e Sport, 1999).

İtalya'da spor kulüplerinin bağlı unsurları genel kurul, başkan, yönetim kurulu ve denetleme kurulundan müteşekkildir. Kulübün yönetim organı olan Genel Kurul, kurucu üyelerden ve aktif üyelerden oluşmaktadır. İtalya'da spor derneklerinin başkanları, üçüncü kişiler ve kanunlar karşısında temsilci ve yasal olarak sorumlu kişilerdir. Başkan, genel kurul ve denetleme kurulu tarafından gerekli yönergelere dayanarak faaliyetlerin yürütülmesinden, bunlarla ilgili raporları hazırlamaktan ve derneğin olağan bir şekle iaresinden sorumludur. Başkan, genel kurul ve yönetim Kurulunu toplayıp ona başkanlık yaparak kararların icrasını sağlamaktadır. Ayrıca işlemlerin tüzük ve yönetmeliklere uygunluğunu denetlemektedir. Dernek, başkan, başkan yardımcısı, sekreter ve farklı sayıda danışmandan müteşekkil bir yönetim kurulu tarafından yönetilir. Yönetim Kurulu olağan toplantısı başkanın davetiyle veya üyelerin çoğunluğunun isteği ile olağanüstü toplanır. Toplantının geçerliliği için üyelerin çoğunluğunun toplantıya gelmesi gereklidir. Kararlar toplantıya katılanların çoğunluğu tarafından alınır. Eşit oy durumunda başkanın oyu sonucu belirler. Başkanın ya da yönetim kurulunun çoğunluğunun istifası durumunda, başkan idareyi düzenleyip olağanüstü kurulun toplanmasını gerçekleştirmekle görevinde kalmak zorundadır. Başkanın kesin olmaması durumunda ise aynı yetkiler başkan yardımcısı tarafından yerine getirilir. Denetleme Kurulu derneğin yönetiminin muhasebe kayıtlarının ve bilanço dengesinin tüzüğe uygunluğunu kontrol etmekle mükelleftir. Kulüp Genel Sekreteri yönetim kurulu kararları gereğince kulübün yapmayı düşündüğü çalışma, idari mali ve teknik tüm işlerin yapılmasıyla yükümlüdür (http://www.coni.it/home/ilconi/leggi-e). 
Dilek İ, Arslan L. (2021). Türkiye ve İtalya Spor Kulüplerinin Örgütsel Yapılarının Kıyaslamalı Analizi. Gaziantep Üniversitesi Spor Bilimleri Dergisi, 6(4), 311-328.

\section{Spor Kulüplerinin Yapılanma Şekilleri}

İtalyan spor kulüpleri yapılanmasının temelinde profesyonel spor kulüpleri ve amatör spor dernekleri de yer almaktadır. Profesyonel spor kulüpleri, kulüpler ve profesyonel 18 sporcu arasındaki münasebete ait kuralları gösteren 1981 tarih ve 91 Sayıı ıasa ile şekillendirilmiştir. Yasanın 10. maddesi sadece anonim şirketler veya sınırlı sorumlu şirketler şeklinde oluşan limitet şirketleri ve profesyonel atletleri kayıt ve şartlara uyduracak biçimde belirler. Sportif dernekleşme ise, "amatör sportif faaliyetler için düzenlemeleri" içeren, 128/2004 olarak değiştirilen, 2002 tarih ve 289 Sayılı Yasa'nın 90. maddesi ile düzenlenmiş̧ir. Bu düzenleme, 17. ve 18. fıkralarda, amatör spor sektöründe çalışan kişilerin sınıflandırılmasını yapmaktadır. Özellikle tüzel kişiliği olmayan spor derneklerinin yanına özel hukuk tüzel kişili spor derneği ile müşterek ve limitet spor kulüpleri eklenmektedir. Amatör spor dernekleri ve kulüpler 2002 tarih ve 289 Sayılı Yasa'nın 90. Maddesine göre gerekli asgari şartları taşımaları ile düzenlenmiştir. 289/2002 Sayılı Yasa'nın 90. maddesinin 20. fıkrasına göre amatör spor kulüpleri ve dernekleri, gerekli şartları taşıdıklarında Ulusal İtalyan Olimpik Komitesi tarafından belirlenen bir sicile kayıt olurlar (Amatör Spor Dernekleri ve Kulüpleri Kanunu, 2002).

Tüzük ve şirket sözleşmesi yanı sıra, sportif çalışma yapan kulüpler kendi ofis ve kuruluşun işleyiş ve organizasyonu için kendi yönetmeliklerini hazırlarlar. Kulüplerde sermayeli ortaklık ya da kooperatif ortaklık şeklinde kurulmuş olup profesyonel olmayan ve kâr amacı taşımayan ortaklıklar 2002 tarihli ve 289 Sayılı Kanunca şekillenmiştir. 2463 ve 2464 Sayılı İtalyan Medeni Kanunu'nun ilgili maddelerinin 4 bendi ile 2002 tarih ve 289 Sayılı Kanun'un 90 maddesinin 17 ve 18 bentlerindeki şartlara uyulmaları şarttır. Kulüplerin şirket şeklinde yapılanması ise 1981 tarih ve 91 Sayılı Yasa'nın 10. Maddesine göre yapılmıştır (Turismo e Sport, 1981).

\section{Mali ilişkiler ve Yardım Ödenekleri}

İtalyan Devleti ile spor kulüpleri arasındaki mali ilişkiler finansal kolaylaştırmalar adı altında icra edilmektedir. Amatör spor kulüplerine tanınan bu kolaylaştırmalar birbirine bağlı gelir tespit defterine uygunluk ve KDV zorunluluğunun basitleştirilmesi şeklinde olmaktadır. Kolaylaştırmalar sabit gelir vergisi oranının belirlenmesiyle KDV'nin tespiti için sabit oranlı bir sistem, muhasebe muafiyeti, envanter tutma muafiyeti, faturalandırma kayıt gereklerinden muafiyet şeklindedir. Amatör spor dernekleri için, 186/2004 Kanunu'ndaki sicile kayıt, amatör sporun yararına cari olan 
Dilek İ, Arslan L. (2021). Türkiye ve İtalya Spor Kulüplerinin Örgütsel Yapılarının Kıyaslamalı Analizi. Gaziantep Üniversitesi Spor Bilimleri Dergisi, 6(4), 311-328.

yönetmelik tarafında öngörülen vergi kolaylıklarından faydalanmasına izin vermektedir. Bu kayıt, amatör derneklerin IRPEF'in 5/1000 oranında ödeneğinden de faydalanmasına izin etmektedir. Ayrıca, sportif etkinlik organizasyonunu ve sportif tecrübeyi geliştirmek amacıyla belediyeler gibi yerel yönetimlerce yapılacak bazı katkı ve kolaylıklar öngörülmüştür. İtalyan Devleti, bölge ve yerel otoriteler arasındaki sorumlulukların paylaşımında Anayasa'nın 117. Maddesinin 3. Kısmını cari kılmıştır. Bazı kolaylaştırmalar yerel yasalarca düzenlenmektedir. Yerel bölgeler, 1998/112 Sayılı Kanun'un 157 maddesinin 1. ve 2. bentlerine göre spor tesisleri ve ilgili araçgereçlerin programlanmasıyla yükümlüdür (http://wwww.coni.it/home/il-coni/leggi-e).

\section{Kayıt, Tescil ve Denetimler}

İtalyan spor kulüpleri, yapısal olarak profesyonel spor kulüpleri ve amatör spor dernekleri olmak üzere ikiye ayrılsa da hukuki konularda Devlet ile sportif kulüp ve şirketler arasındaki ilişkiler 17 Ekim 2003 tarih ve 280 Sayılı Yasa'nın 1. maddesi ile düzenlenmiştir. Spor kulüpleri örgütlenmesinin özerklik ilkesi dikkate alınarak hazırlandığı organizasyon, sportif tecrübenin ilerlemesi, (CIO) Uluslararası Olimpiyat Komitesi'nin ilanı, (CONI) Ulusal İtalyan Olimpiyat Komitesi'ne aittir (http:// www.coni.it/home/il-coni/leggi-e).

\section{Bulgular}

Araştırma bulguları Türkiye ve İtalya'daki spor kulüplerinin kuruluş, örgütlenme şekilleri, ulusal spor yönetimi içerisinde yeri ve işlevleri, devlet ile spor kulüpleri arasındaki ilişkiler, spor federasyonları başkanlık seçiminde spor kulüplerinin oy kullanma oranları, spor kulüplerinin sürdürülebilirliği açısından devlet tarafından verilen destekler ile spor kulüplerinin denetiminin nasıl gerçekleştiklerine ilişkin bilgileri kapsamaktadır.

\section{Türkiye ve İtalya Spor Kulüplerinin Örgütsel Yapılarının Karşılaştırmalı Analizleri}

\section{Spor Kulüplerinin Bağlı Oldukları Mevzuatlar}

Italya'da spor kulüpleri, ülke yasalarına göre bir derneklerde olduğu gibi idari makamların izin ve resmi bir senet ile kurulabilmektedir. Ayrıca İtalya'da spor kulüpleri bazı mevzuat hükümlerine göre çalışmalarını sürdürmektedir. Bu mevzuat CONI tüzüğü, kulüpler ve profesyonel sporcular arasındaki ilişkileri düzenleyen kurallar, amatör sportif çalışmalar için hazırlanan düzenlemelerin havi olduğu 2002 tarih ve 289 Sayılı Kanun'un 90 maddesi, 2003 tarih ve 220 Sayılı Kanun Hükmünde Kararname, 
Dilek İ, Arslan L. (2021). Türkiye ve İtalya Spor Kulüplerinin Örgütsel Yapılarının Kıyaslamalı Analizi. Gaziantep Üniversitesi Spor Bilimleri Dergisi, 6(4), 311-328.

Spor Hukukuna İlişkin Acil Kararname ile1999 tarih ve 242 Sayılı Kanun Hükmünde Kararnamelerdir. Türkiye'de spor kulüpleri 5253 Sayılı Dernekler Kanunu'nun “Gençlik ve Spor Kulüpleri” başlıklı 14 maddesi ile son halini almıştır (Üçışık, 2011).

Türkiye'de kulüplerin vazife ve yetkileri, uymak zorunda oldukları esaslar, üst kuruluş oluşturmada uyacakları esaslar ve usullerle denetlenmeleri Bakanlar Kurulu tarafından hazırlanan Gençlik ve Spor Kulüpleri Yönetmeliği'yle şekillenmiştir. Ayrıca spor kulüplerine yapılacak her türlü yardımın şekil ve şartları Spor Genel Müdürlüğü tarafından hazırlanan Spor Kulüpleri Yardım Yönetmeliği'nde yasallaşmıştır (Ertaş ve Petek, 2005). Sporda devlet yönetimiyle gönüllü birlik türünden örgütlenmeleri birbirinden ayırabilmek için hukuka dayalı olarak uygulanabilecek en doğru ölçüt, kamu-özel hukuk tüzel kişileri ayrımı yapılmasıdır (Fişek, 2003).

Italya'da spor kulüplerinin temeli profesyonel ve amatör spor dernekleridir. Profesyonel spor kulüpleri, kulüpler ve profesyonel sporcular arasındaki ilişkilere yönelik kuralları içeren 1981 tarih ve 91 Sayılı Kanun'un 17'nci ve 18'inci fıkralarında belirtilen amatör spor alanındaki aktör türleri tanımlamasına uygun olarak tüzel kişiliği olmayan spor dernekleri olarak görülmektedir. Bunlar özel hukuk tüzel kişiliğine sahip spor kulübü ve kâr amacı taşımayan sermaye ve kooperatif şeklinde örgütlenebilmektedir. Türkiye'de ise Dernekler Kanunu ile teşkil olan ve Spor Genel Müdürlüğü'ne dâhil olan spor kulüpleri, sadece Dernekler Kanunu'na göre kâr amacı taşımayan özel hukuk tüzel kişiliğine sahip dernekler olarak örgütlenmişlerdir (Fişek, 2003; Meclis Araştırma Komisyonu Raporu, 2011).

Tablo 1. Spor Kulüplerinin Her iki Ülkede Bağlı Olduğu Mevzuat

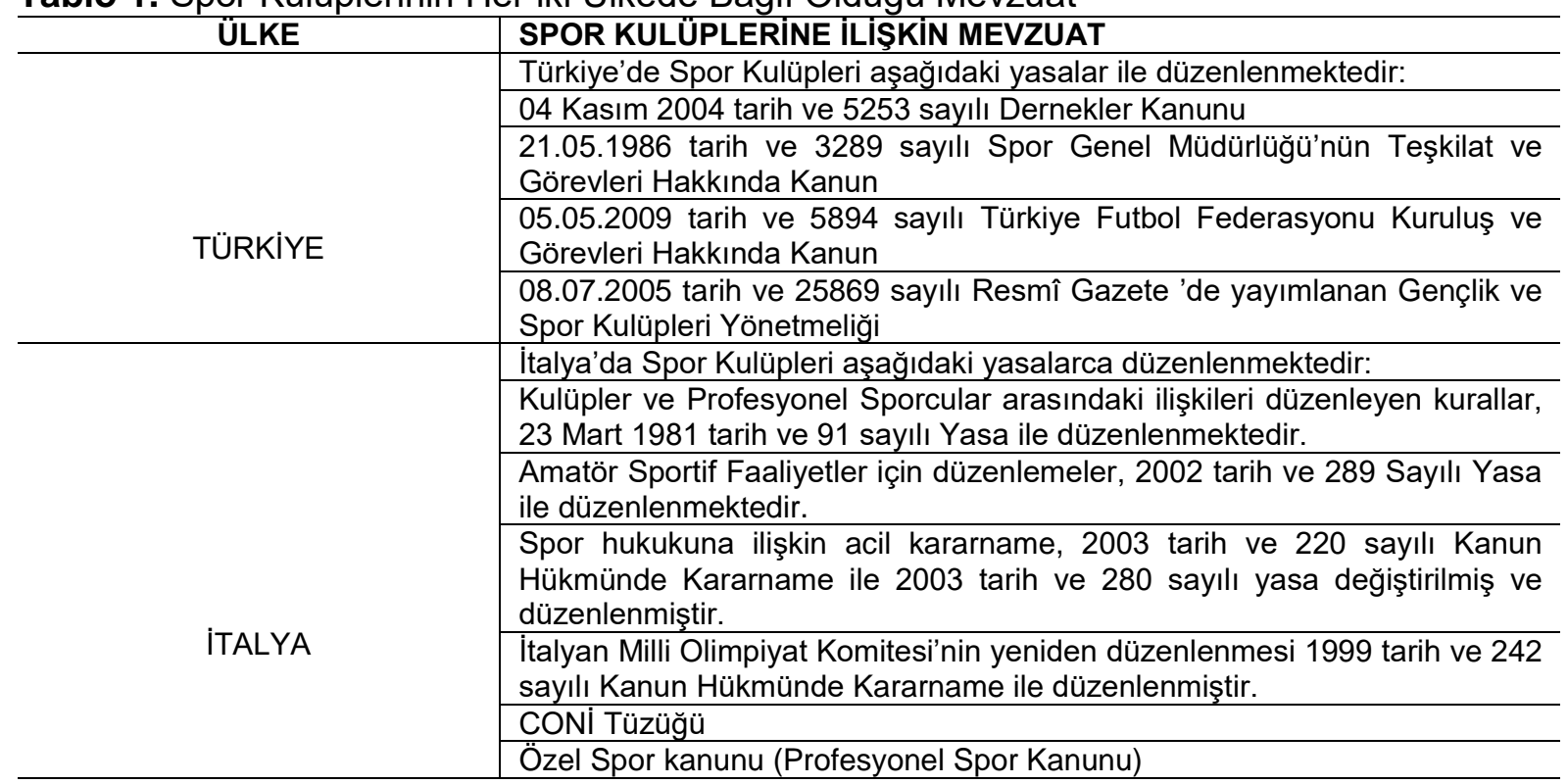


Tablo 1'den de anlaşılacağı üzere, İtalya'da spor kulüplerinin amatör ve profesyonel olarak tanımlanmaları kulüp tüzüklerinin farklııı göstermesinden kaynaklanmaktadır (Fişek, 2003). Türkiye'de ise dernek mevzuatı gereğince derneğin tüzüğü içerisinde derneğin adı, merkezi, amacı ve bu amacı gerçekleştirmek için sürdürülecek çalışma konuları çalışma biçimleri ile faaliyet alanı belirtilmek zorundadır. Derneğe veya kulübe üye olma ve üyelikten çıkmanın şartları, genel kurulun toplanma şekli ve zamanı, genel kurulun görevleri, yetkileri, oy kullanma ve karar alma usulleri yönetim ve denetim kurullarının görev ve yetkileri de belirtilmek durumundadır. Derneğin veya kulübün şubelerinin olup olmadığı, görev ve yetkileri ile dernek genel kurulunda nasıl temsil edileceği, üyelerin ödeyecekleri giriş ve yıllık aidat miktarının belirlenme şekilleri açıkça yazıımalıdır. Gelir kaynakları, derneğin borçlanma usulleri, derneğin iç denetim şekilleri, tüzüğün ne şekilde değiştirilebileceği, derneğin feshi halinde mal varlığının tasfiye şeklinin belirtilmesi ise ayrı bir gerekliliktir. Türkiye'de ayrıca spor kulüpleri 3289 Sayılı Kanun'la profesyonel takımlarını Türk Ticaret Kanunu hükümlerine göre de kuracakları veya kurulmuş olan şirketlere devredebilecekleri, kiraya da verebilecekleri de kabul edilmiştir (Erten, 2006).

Tablo 2. Türkiye ve İtalya'daki spor kulüplerinin örgütlenme şekilleri

\begin{tabular}{|c|c|}
\hline ÜLKE & SPOR KULÜPLERININ ÖRGÜTLENME ŞEKILLERI \\
\hline \multirow{3}{*}{ TÜRKIYE } & Türkiye'de Spor Kulüpleri aşağıdaki şekillerde örgütlenebilmektedir: \\
\hline & Dernek Şeklinde \\
\hline & Hem dernek hem de şirket şeklinde \\
\hline ÜLKE & SPOR KULÜPLERININ ÖRGÜTLENME ŞEKILLERI \\
\hline \multirow{8}{*}{ ITALYA } & İtalya'da Spor Kulüpleri aşağıdaki şekillerde örgütlenmektedir: \\
\hline & Profesyonel Spor Kulüpleri \\
\hline & Limited Şirketler \\
\hline & Anonim şirketler \\
\hline & Amatör Spor Kulüpleri \\
\hline & Tüzel Kişiliği Olmayan Spor Dernekleri \\
\hline & Özel Hukuk Tüzel Kişiliğe Sahip Spor Kulübü \\
\hline & Sermaye ve Kooperatif Şeklinde Spor Kulüpleri \\
\hline
\end{tabular}

Tablo 1 ve 2 incelendiğinde, Türkiye ve İtalya'daki spor kulüplerinin dernekler yasası ve özel bazı yönetmeliklere göre teşkilatlandıkları görülmektedir. Ancak uygulamada farklııklar bulunmaktadır. İtalya'da profesyonel spor kulüpleri anonim şirket ya da limited şirket şeklinde kurulabilmektedir. Türkiye'de ise spor kulüpleri Dernekler Kanunu'na göre yapılandırılmıştır. 
Dilek İ, Arslan L. (2021). Türkiye ve İtalya Spor Kulüplerinin Örgütsel Yapılarının Kıyaslamalı Analizi. Gaziantep Üniversitesi Spor Bilimleri Dergisi, 6(4), 311-328.

İtalya'da profesyonel spor kulüpleri, sadece sportif faaliyetlerle ilişkili şirket esas sözleşmesini hazırlamak zorundadırlar. Profesyonel spor kulüplerinin faaliyetlerini yürütebilmesi içinse kuruluşun anonim şirket ya da limited şirket şeklinde bir özel kuruluş olması, uygun bir oyun alanının bulunması ve ilgili federasyon yönetmeliklerinin öngördüğü biçimde sporcular ve teknik uzmanlarla sözleşmelerin yapılması gereklidir. Türkiye'de ise dernek mevzuatı gereğince derneğin tüzüğü içerisinde derneğin adı ve merkezi, amacı ve bu amacı gerçekleştirmek için sürdürülecek çalışma konuları çalışma biçimleri ile faaliyet alanı belirtilmelidir.

Tablo 3. Türkiye ve İtalya'da Spor Kulüpleri ile Devlet Arasındaki İlişki

\begin{tabular}{|c|c|}
\hline ÜLKE & SPOR KULÜPLERI İLE DEVLET İLIŞKISİ \\
\hline \multirow[b]{3}{*}{ TÜRKIYE } & Devlet spor kulüpleri ile ilgili yasal mevzuatı düzenler ve denetler \\
\hline & Devlet sporun özerk yapısını tanır ve destekler \\
\hline & $\begin{array}{l}\text { Devlet spor kulüplerinin faaliyetlerini daha iyi yürütebilmelerini } \\
\text { sağlamak amacıla yardım ödeneği (tesis bakımı, onarımı, ayni } \\
\text { nakdi yardım vb) sağlar. }\end{array}$ \\
\hline \multirow[b]{4}{*}{ ITALYA } & Devlet ile Spor Kulüpleri ilişkileri yasa ile düzenlenir. \\
\hline & Devlet sporun özerk yapısını tanır ve destekler \\
\hline & $\begin{array}{l}\text { Profesyonel spor faaliyetleri, } 1980 \text { tarih ve } 91 \text { sayılı Kanun ve } \\
\text { kanunlara uygun olarak hazırlanan hizmet akdi (çalışma } \\
\text { sözleşmeleriyle) düzenlenir. }\end{array}$ \\
\hline & $\begin{array}{l}\text { İtalya Hukuk Sistemi altında spor sektörünü yöneten genel çerçeve, } \\
\text { farklı yapıdaki kanunların (iç hukuk, CONI mevzuatı, Ulusal } \\
\text { Federasyonların yönetmelikleri, kimi zaman Uluslararası Spor } \\
\text { Federasyonları kuralları) etkileşimi sonucunda yapılmıştır }\end{array}$ \\
\hline
\end{tabular}

Tablo 4. Türkiye ve İtalya'da Spor Kulüplerinin Kurulması için Uygulanan Prosedürler

\begin{tabular}{|c|c|}
\hline ÜLKE & $\begin{array}{llll}\text { SPOR } & \text { KULÜPLERININ } & \text { KURULMASINDA } & \text { UYGULANAN } \\
\text { PROSEDÜRLER } & & \end{array}$ \\
\hline \multirow{4}{*}{ TÜRKIYE } & $\begin{array}{l}\text { Gerçek veya tüzel en az yedi kurucu tarafından doldurulan ve } \\
\text { imzalanan kuruluş bildirim formu }\end{array}$ \\
\hline & $\begin{array}{l}\text { Dernek kurucuları tarafından her sayfası imzalanan dernek tüzüğü } \\
\text { İçişleri Bakanlığı Dernekler Dairesi Başkanlığına teslim edilir }\end{array}$ \\
\hline & $\begin{array}{l}\text { Dernekler kütüğüne kayıt edildikten sonra spor dernekleri, SGM } \\
\text { Kanunun 20'nci maddesi uyarınca Spor Genel Müdürlüğü } \\
\text { tarafından tutulan sicile kayıt ve tescil edilir. }\end{array}$ \\
\hline & $\begin{array}{l}\text { Kulübün faaliyetlerine katılacağı branşlarda ilgili federasyonlara } \\
\text { tescil işleminin yaptırılır. }\end{array}$ \\
\hline \multirow{9}{*}{ İTALYA } & Profesyonel Spor Kulüplerinin Kurulmasında \\
\hline & - Tüzük ve Şirket Esaslı Sözleşmenin şarta bağlanması \\
\hline & - İlgili Federasyona kaydı (Yapılan faaliyetle ilişkili olarak) \\
\hline & - Şirketler siciline kaydı \\
\hline & - İlgili Federasyon bünyesinde şirket esaslı sözleşme depozitosu \\
\hline & Amatör Spor Kulüplerinin Kurulmasında \\
\hline & - Tüzük ve şirket esaslı sözleşmenin şarta bağlanması \\
\hline & -illgili federasyona kaydı (Müsabakalara katılma şartı) \\
\hline & Kanunla tayin edilen bir sicile kayıt olma \\
\hline
\end{tabular}

Her iki ülke arasında spor kulüplerinin kurulmasında spor kulüplerinin amatör ve profesyonel olmaları bakımından farklı prosedürler uygulanmaktadır. Ancak spor 
Dilek İ, Arslan L. (2021). Türkiye ve İtalya Spor Kulüplerinin Örgütsel Yapılarının Kıyaslamalı Analizi. Gaziantep Üniversitesi Spor Bilimleri Dergisi, 6(4), 311-328.

kulüplerinin faaliyetlere katılacağı branşlarda ilgili federasyonlara tescil işlemi yaptırmaları benzer olarak değerlendirilebilir.

Tablo 6. Türkiye ve İtalya'da Spor Kulüplerinin Denetimi

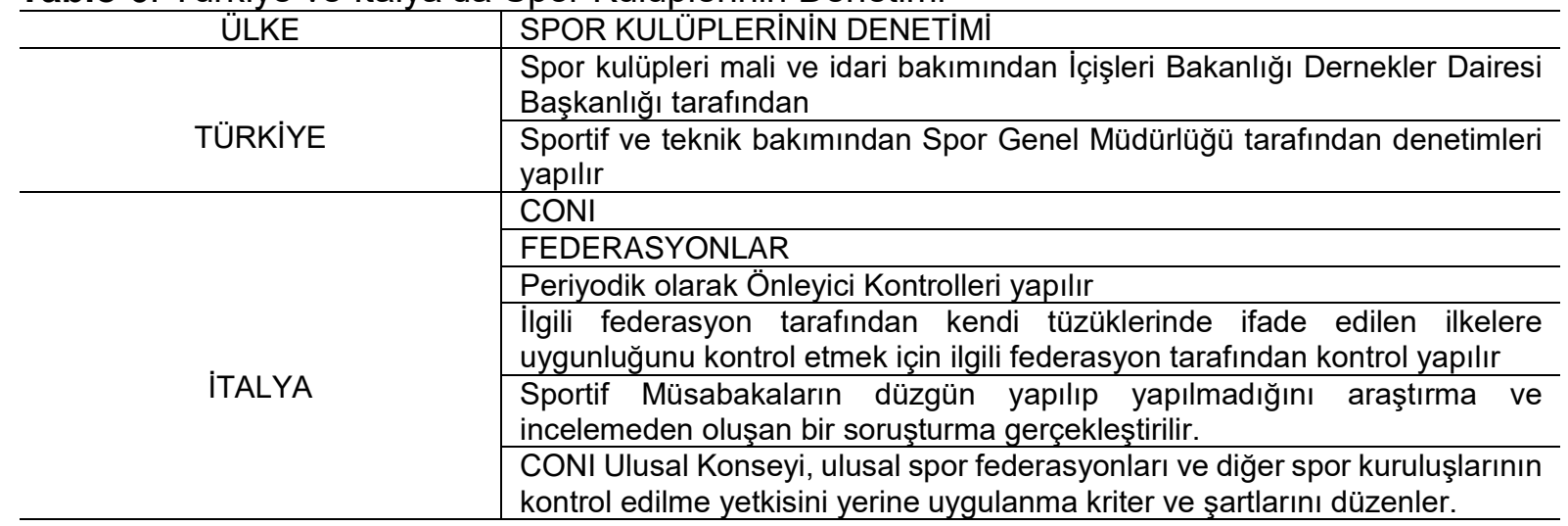

Tablo 5'ten de görüleceği üzere her iki ülkede spor kulüplerinin denetimleri de farklılık göstermektedir. İtalya'da CONi Ulusal Konseyi sportif yarışmaların dengesini korumak amacıyla CONI (İtalya Milli Olimpiyat Komitesi) ile Ulusal Spor Federasyonlarına bir takım denetim ve kontrol görevleri vermiştir. İtalya'da Ulusal Spor Federasyonları yönetmelikleri doğrultusunda periyodik olarak bir takım önleyici kontroller uygulamaktadır. Türkiye'de spor kulüpleri mali ve idari bakımdan İçişleri Bakanlığı Dernekler Dairesi Başkanlığı tarafından denetimleri yapılırken, teknik ve sportif açıdan Spor Genel Müdürlüğü tarafından yapılmaktadır. Türkiye'de spor federasyonlarının spor kulüplerini denetleme yetkileri yoktur. Türkiye'de spor kulüplerinin denetimleri Spor Genel Müdürlüğü veya mülki idare amirinin onayı alınmak kaydıyla Gençlik Hizmetleri ve Spor İ Müdürleri tarafından Dernekler Kanunu göz önüne alınarak yapılmaktadır.

\section{Tartışma ve Sonuç}

Türkiye ve İtalya'daki spor kulüplerinin mevcut durumları örgütsel yapıları, spor kulüplerinin yeri ve işlevleri, devletle olan ilişkileri ve denetimleri bakımından benzer ve farklılıkları bulunmaktadır. İtalya'da spor kulüpleri örgütlenme şekilleri olarak daha çok amatör ve profesyonel spor kulüpleri olarak tanımlanmıştır. Spor kulüplerinin örgütlenmeleri, faaliyetlere katılma şekilleri, devletle olan ilişkileri, tabi oldukları mevzuatlar kanunla belirlenmiştir. Türkiye'de ise spor kulüpleri daha çok amatör düzeyde faaliyetlerini sürdürmekle birlikte spor branşları profesyonel ve amatör olarak tanımlanmıştır. Bu bakımından Türkiye'de her ne kadar futbol branşında profesyonel faaliyetler uygulanmakta ve şirketleşmelere müsaade edilmekteyse de İtalya'da olduğu gibi spor kulüpleri anonim şirket ya da limitet şirketi şeklinde değil daha çok branşların 
Dilek İ, Arslan L. (2021). Türkiye ve İtalya Spor Kulüplerinin Örgütsel Yapılarının Kıyaslamalı Analizi. Gaziantep Üniversitesi Spor Bilimleri Dergisi, 6(4), 311-328.

sportif anonim şirketi ya da limitet şirketi şeklinde düzenlendikleri anlaşılmaktadır. Türkiye ve İtalya'daki spor kulüplerinin denetimleri bakımından da önemli farklılıkları bulunmaktadır. Türkiye ve İtalya'da spor kulüplerinin devletle olan ilişkileri, spor kulüplerinin kurulması ve tüzüğün hazırlanma prosedürleri ve yerine getirmeleri gereken minimum şartlar ile uygulama esasları bakımından benzerlik göstermektedir. Dünya'da özellikle Avrupa'da spor kulüplerinin örgütlenmesinde ilerlemiş ülkeler ile Türkiye'deki spor kulüplerinin örgütlenme yapıları ve mevcut durumları neden-sonuç ilişkisi içerisinde karşılaştırmalı olarak analiz edilerek spor kulüplerine ilişkin daha etkin ve verimli örgütlenme modellerinin oluşturulması sportif faaliyetlere hız kazandıracağı gibi ekonomik olarak da fayda sağlayacaktır. Amatör ve profesyonel spor kulüplerinin yasal mevzuatta tanımları yapılarak örgütlenme usul ve esasları yeniden belirlenmeli ve spor kulüpleri yönetimine gerekli destekler devlet ve gönüllü kuruluşlarca sağlanmalıdır.

\section{Kaynaklar}

Akşar, T. (2005). Endüstriyel Futbol. Literatür Yayıncılık, İstanbul.

Arslanoğlu, İ. (2012). Sosyal Bilimlerde Metot ve Araştırma Teknikleri. Gazi ÜniversitesiYayınları,Ankara.http://www.google.com.tr/\#hl=en\&tbo=d\&sclient= psyab\&q=Arslanoğlu\%2C+l. + +Sosyal+bilimlerde+metod+ve+araştırma+teknikle rii\& (erişim tarihi: 23.10.2012).

Aydın, A. D. (2005). Spor Kulüplerinin Halka Açılmasının Finansal Yapıları Üzerine Etkileri. (Yayınlanmamış Doktora Tezi), Gazi Üniversitesi Sağlık Bilimleri Enstitüsü, Ankara

Communication on sport, (2011). Publications Office of the EU, www.Communication on sport (2011)- Publications Office of the EU. Adresinden alınmıştır.)

CONI Principi Fondamentali Degli Statuti, Delle Federazioni Sportive Nazionali, Delle Discipline sportive" (2012). Principi Fondamentali degli Statuti delle Federazioni Sportive Nazionaliedelle Discipline Associate, http://www.coni.it/images/documenti/PrincipiFondamentaliFSNDSAdelibera14 58_CN_del_2-2-2012.pdf Adresinden alınmıştır.

Coordinatore Dell'Ufficioperlo Sport Presidenza Del Consiglio Dei Ministri Dipartimento Affari Regionali, Turismo e Sport 
Dilek İ, Arslan L. (2021). Türkiye ve İtalya Spor Kulüplerinin Örgütsel Yapılarının Kıyaslamalı Analizi. Gaziantep Üniversitesi Spor Bilimleri Dergisi, 6(4), 311-328.

Devecioğlu, S., Çoban, B., \& Karakaya, Y. E. (2011). Spor Kulüplerinin Yönetim Modellerinin Değerlendirilmesi. Dumlupınar Üniversitesi Sosyal Bilimler Dergisi, (31).

Ecer, E. G. (2009). Avrupa Birliği Özel Tüketim Vergisi Sisteminde Vergi Antrepoları.

T.C. Maliye Bakanlığı AB ve Dış İlişkiler Dairesi Başkanlığı Bülteni, Ankara.

Ekenci, G. (1997). İnsan ve Çevre İlişkilerinin Spor Kulübü Yönetimine Etkileri. Gazi Üniversitesi Beden Eğitimi ve Spor Bilimleri Dergisi, 2 (4),

Ertaş, Ş. ve Petek, H. (2017). Spor Hukuku. Yetkin Yayınları, Ankara.

Erten, R. (2006). Türk Sporunun Yapısal Düzeni. Gazi Üniversitesi Hukuk Fakültesi Dergisi, 10 (1), 117-136.

Erturan Öğüt, E. E. ve İmamoğlu F. (2011). Almanya ve Türkiye'deki Spor Kulüplerinin Karşılaştırmalı Analizi: Türkiye'deki Spor Kulüplerinin Yapı ve İşleyişine Yeni Bir Yaklaşım. Hacettepe Üniversitesi Spor Bilimleri Dergisi, 22 (2), 54-68

Erturan, Ö. E. E. (2010). Almanya ve Türkiye'deki Spor Kulüplerinin Karşılaştırmalı Analizi-Türkiye'de Spor Kulüplerinin Yapı ve İşleyişine Yeni Bir Yaklaşım. (Yayınlanmamış Doktora Tezi), Gazi Üniversitesi Sağlık Bilimleri Enstitüsü, Ankara.

Fişek, K. (2003). Devlet Politikası ve Toplumsal Yapıyla İlişkileri Açısından Spor Yönetimi: Dünya'da ve Türkiye'de. Mart Matbaası, İstanbul.

Genç, D. A. (1998). Spor Hukuku, Alfa Kitapevi, İstanbul.

Gençlik ve Spor Kulüpleri Yönetmeliği, (B.K.K. 26.3.1985-85/9562). T.C. Resmî Gazete, Sayı 18825; Tarih 1985

Spor Genel Müdürlüğü'nün Teşkilat ve Görevleri Hakkında Kanun, T.C. Resmî Gazete, Sayı 19120; 28 Mayıs 1986.

https://www.mevzuat.gov.tr/mevzuat?MevzuatNo=9012\&MevzuatTur=7\&MevzuatTert ip $=5$

Http://www.coni.it/home/il-coni/leggi-e statuto/controlli-delle-federazioni-sulle-societàprofessionistiche.html).

Karasar, N. (1997). Bilimsel Araştırma Yöntemi. 7.basım, Ankara.

Karasu, K. (2004). Kamu Yönetimi Ülke İncelemeleri. İmge Kitabevi, Ankara.

Kırcaali iftar,G. (1999). Sosyal Bilimlerde Araştırma Yöntemleri. Bir A. A. (Editör), Anadolu Üniversitesi Yayınları, Eskişehir. 
Dilek İ, Arslan L. (2021). Türkiye ve İtalya Spor Kulüplerinin Örgütsel Yapılarının Kıyaslamalı Analizi. Gaziantep Üniversitesi Spor Bilimleri Dergisi, 6(4), 311-328.

Meclis Araştırma Raporu: Spor Kulüplerinin Sorunları ile Sporda Şiddet Sorununun Araştırılarak Alınması Gereken Önlemlerin Belirlenmesi Amacıyla Kurulan Meclis Araştırma Komisyon Raporu. (2011). TBMM, Ankara.

Sunay, H. (2009). Spor Yönetimi. Gazi Kitabevi, Ankara.

Süreç, Y. ve Aktifler, Ü. (2009). Rekabet Edebilirlik Raporu: Kuzey Kıbrıs Rekabet Edebilirlik Raporu 2008-2009. Kuzey Kıbrıs Türk Cumhuriyeti.

Üçışık, F. (2011). Spor Hukuku. Yaylacık Matbaası, İstanbul.

Yıldız, I. S. (2009). Kırıkkale ili Spor Kulüplerinin Faaliyet Alanları ve Işsleyişi. (Yayınlanmamış Yüksek Lisans Tezi). Kırıkkale Üniversitesi Sağlık Bilimleri Enstitüsü, Kırıkkale. 